Ankara Üniversitesi

SBF Dergisi,

Cilt 67, No. 4, 2012, s. 63-88

\title{
ANAYASA MAHKEMESININ BELEDIYE MECLISLERININ VERGILENDIRME YETKiSIYLE ILGILI KARARINA ILIŞKIN Bir DEĞERLENDIRME
}

\author{
Doc. Dr. N. Semin Öz \\ Ankara Üniversitesi \\ Siyasal Bilgiler Fakültesi
}

\section{Özet}

Demokrasi geleneklerine ve idari yapılanma biçimlerine bağlı olarak belediye meclislerinin vergilendirme yetkisi ülkeden ülkeye farklılıklar göstermektedir. Sanayi devrimi sonrasında kentleşme olgusunun önemi artarken, yerel yönetimlerin görev ve sorumluluklarını artması, bu yönetimlerin kaynak gereksinimlerini de beraberinde getirmiștir. Benzer durum Türkiye için de geçerli olmuștur. Türkiye'de yerel yönetimler konusunda Cumhuriyetin ilk yıllarında Osmanlı Devletinden kalan uygulamalar büyük ölçüde sürdürülmüştür. 1948 yılında uygulamaya giren 5237 sayılı Belediye Gelirleri Kanununda, belediye meclislerine Yasada alt ve üst sınırları verilen maktu vergi, resim ve ücretleri belirleme yetkisi verilmiștir. Bu uygulama kısmen 1981 yılında yürürlüğe giren 2464 sayılı Belediye Gelirleri Kanununda devam etmiş̧tir. Ancak 1982 Anayasasının vergilendirme ile ilgili kurallarının belediye meclislerine bu yetkiyi verip vermediği, uzun süre tartışma konusu olmuştur. Bu konuya ilişkin olarak Anayasa Mahkemesi, geçtiğimiz günlerde verdiği bir kararında, belediye meclislerinin vergi tutarını belirleme yetkisinin olmadığı sonucuna varmıştır. Bu makalenin konusunu, Türkiye'de belediye meclislerinin vergilendirme yetkilerinin tarihsel perspektif içerisinde ve Avrupa Yerel Yönetimler Özerklik Şartı ile bağlantısı kurularak değerlendirilmesi oluş̧urmaktadır.

Anahtar Sözcükler: Mali tevzin, belediye gelirleri, vergilendirme, emlak vergisi, vergilendirme yetkisi

An Evaluation of the Constitutional Court's Judgement on the Authority of Municipal Councils

\begin{abstract}
The taxation power of municipal councils varies from country to country depending on the democracy traditions and their administrative structures. Following the industrial revolution, the importance of urbanization phenomenon has increased. The revenue need of the local governments has also increased with their enlarging duty and responsibilities. A similar situation is also valid for Turkey. Regarding the issue of local governments, the Ottoman regulations were mostly maintained in the early years of the Republic. The rule of law numbered 5237, came into force in 1948, gave the authority to the municipal council to determine the amount of taxes and duties within the upper and lower limits established in the law. This situation preserved partially in the law numbered 2464 which took effect in 1981 . However, there has been a long debate arguing whether the taxation regulations in the 1982 Constitution gave this right to the municipal councils. The aim of this paper is to evaluate the taxation rights of municipal councils in a historical perspective in relation to the European Charter of Local Self Government.
\end{abstract}

Keywords: Decentralization, municipality income, taxation, property tax, taxing power 


\section{Anayasa Mahkemesinin Belediye Meclislerinin Vergilendirme Yetkisiyle İlgili Kararına İlişkin Bir Değerlendirme}

\section{Giriş}

Kamu hizmetlerinin yürütülmesinde, merkezi yönetimler ile yerel yönetimler arasında görev ve gelir paylaşımı, "merkeziyetçilik" ve "ademi merkeziyet" ilkeleri ile "mali tevzin" kavramının sıkça gündeme gelmesine neden olmaktadır. Bu paylaşımda, yerel idarelere düşen görev payının artması, bu yönetimlerin gelire olan gereksinimini arttırmaktadır. Yerel yönetimlerin gelirleri doğal olarak tüm kamu yönetimlerinde olduğu gibi esas itibariyle vergiye dayanmaktadır. Tarihsel süreç içerisinde yerel yönetimlerin vergi gelirleri başlangıçta tek bir vergiye, çoğunlukla emlak vergisine dayanmıştır. Daha sonra emlak vergisi yanında işletme vergisi ve son olarak da bunlara ilave olarak işlem vergileri, yerel yönetimlerin gelir kaynakları arasında yer almıştır.

Yerel idareler, siyasal hukuki bir kavram ve sosyal-idari bir kurum olarak geç ortaçağlar Avrupa'sının ürünüdür (Ortaylı, 1982:137) Neolitik devrimden sonraki süreçte sanayileşme olgusunun ortaya çıkmasıyla kent yaşamı önem kazanmaya başlamıştır. Yerel idarelerin sundukları kamu hizmetleri, başlangıçta fazla değildir. Buna bağlı olarak vergi gelirleri, bu idarelere yeterli gelirken daha sonra kentlere göç eden birey sayılarının artması ve anakentlerin (metropollerin) ortaya çıkmasıyla birlikte yerel idarelerin gelir kaynaklarını artırıcı düzenlemeler ön plana çıkmaya başlamışıı. Dolayısıyla yerel idare ile merkezi idare arasında hizmet bölüşümüne paralel olarak idareler arası gelir paylaşımı da önem kazanmaya başlamıştır. Özellikle federal yapıya sahip devletlerde, federe devlet ile federal devletin aynı vergi matrahı üzerinden vergi alması, beraberinde aynı ülke içerisinde gerçekleşen "dikey vergi rekabeti" tartışmalarını da beraberinde getirmektedir. 
Yerel idarelerin, vergi gelirlerine olan gereksinimlerinin artmas1, bu yönetimlerin vergiyi doğuran olaylar ile vergi matrahlarını kendilerinin tanımlaması ve vergi oranını kendilerinin belirleme yetkisine sahip olup olmaması konusundaki farklı görüşleri de beraberinde getirmektedir ${ }^{1}$. Devletler, yerel idarelerin vergilendirme yetkisine sahip olup olmamas1 konusunda farklı yaklaşımlara sahiptirler. Bazı devletler yerel idarelerin vergilendirme yetkisine sahip olmasını kabul ederken, bazı devletler buna izin vermemektedir. Bazı devletlerse bu iki karşıt yöntemin dışında, sadece vergi oranını ya da vergi matrahını belirleme gibi ara yöntemleri kabul etmektedirler. Merkezi idare ile bölgesel devlet ve/veya yerel idarelerin toplam vergi gelirlerinden aldıkları paylar, geleneksel yapılarına ve ülkelerin idari yapılarına da bağlı olarak ülkeden ülkeye değişebilmektedir² ${ }^{2}$.

$\mathrm{Bu}$ çalışmada, önce Cumhuriyetin kuruluşundan bu yana Türkiye'de belediye meclislerinin vergilendirme yetkisine sahip olup olmadıkları, belediye gelirleriyle ilgili yasalar ve bu yasaların uygulandığ 1 dönemde geçerli olan Anayasa kuralları açısından araştırılmış, daha sonra halen uygulanmakta olan 2464 sayılı Belediye Gelirleri Kanununun belediye meclislerine verdiği alt üst limitler içerisinde vergi tutarını belirleme yetkisiyle ilgili kuralı geçtiğimiz günlerde iptal eden Anayasa Mahkemesi Kararı değerlendirilmiştir. Anayasa Mahkemesinin Kararı, 1982 Anayasasının belirli bir dönemde Türkiye'de çıkarılan yasalara karşı Anayasa Mahkemesinde dava açılmasını yasaklayan geçici 15'inci maddesi ve Avrupa Yerel Yönetimler Özerklik Şartının belediye meclislerinin yasanın koyduğu sınırlar içerisinde yerel vergi ve harçlar konusunda karar verebilmesinin sağlanması ilişkin kuralı ile birlikte ele alınmıştır.

\footnotetext{
${ }^{1}$ Sosyal malların yerel idarelerce sağlanması karşı olan tezlerin arasında "Mahalli idarelere kamu hizmetlerinin devri halinde; mahalli idareler, vergi yükünü düşük tutabilmek için kamu hizmetlerini etkin düzeyin altında sağlayabilirler" yaklaşımı da bulunmaktadır. Bkz. Akalın, 1994:13-14..

2Örneğin 2009 yılında federal idari yapıya sahip Almanya'da merkezi devletin toplam vergi gelirlerinden aldığı pay \% 31,3 iken Avustralya'da \% 80,2'dir. Buna karşılık Almanya'da toplam vergi gelirinin bölgesel devletler (state or regional government) $\%$ 22,3, yerel yönetimler (local government) ise 7,8'ini almaktadır (Toplam vergi gelirleri içerisinde sosyal güvenlik primlerinin payı $\% 38,7$ 'dir). Avustralya'da ise bu oranlar bölgesel devlet için \% 16,4 yerel yönetimler için \% 3,5'dir. Görüleceği üzere federal yapıya sahip bu iki devlet arasında merkezi idarenin toplam vergi gelirlerinden aldığı paylar arasında ciddi farklılıklar bulunmaktadır. Benzer durum, merkezi idari örgütlenmeye sahip devletler içinde geçerlidir. Örneğin, merkezi idarenin toplam vergi gelirlerinden aldığı pay 2009 yılında Fransa'da \% 31, Yeni Zelanda'da \% 93, Türkiye'de ise \% 66,7'dir. Bkz. OECD, 2011: 26.
} 


\section{Belediye Meclislerinin Vergilendirme Yetkisi}

Belediye meclisi, belediyenin karar organıdır ve ilgili yasalarda gösterilen esas ve usullere göre seçilmiş üyelerden oluşmaktadır ${ }^{3}$. Belediye meclislerine vergi alma konusunda yetki tanınmasının siyasi, iktisadi ve hukuki boyutları bulunmaktadır. Yerel idarelerin kendilerine sağlanacak mali olanaklarla birlikte daha fazla sayıda hizmetin görülmesinden sorumlu kılınması ve merkezi hükümetin denetiminden mutlaka kurtarılması (Keleş, 1965:421-22) görüşü, konuyu iktisadi ve siyasi boyutuyla ele almaktadır. Konunun hukuksal boyutu ise parlamentoların sahip oldukları vergilendirme yetkisini yerel idarelerle paylaşmaları konusunda anayasalarda yer alan kurallarla ilgili olarak değerlendirilmektedir. Yerel yönetimlerin vergilendirme yetkisinin sınırı, bu yönetimlerin vergi matrahı ve oranını belirleyebilme yetkisine sahip olmalarından, bu konularda hiçbir yetkiye sahip olmamalarına kadar değişen bir yelpaze içerisinde değişebilmektedir (Öz, 2005:23). Ayrıca yerel ve merkezi yönetimler, toplanan vergi gelirlerini paylaşabilmektedirler. $\mathrm{Bu}$ durumda, merkezi yönetim ile yerel yönetim arasında gelir paylaşımına ilişskin düzenlemeler çoğunlukla devletlerin anayasalarında yer almaktadır ${ }^{4}$.

Son dönemlerde yerel idarelere tanınan yetkilerin birçok ülkede arttığ 1 gözlemlenmektedir. Örneğin, İspanya, İtalya, Belçika ve Fransa gibi ülkelerde yakın geçmişte izlenen gelişmeler merkezi devletle yerel yönetim birimleri arasındaki görev ve yetki bölüşümünün yeniden yapılandırılmasına ve yerel yönetimlerin yetki alanlarının genişlemesine neden olmuştur (Çubukçu, 2010:118). Benzer hizmet artış1, kentleşen nüfus oranı arttıkça Türkiye içinde geçerli olmaktadır. $\mathrm{Bu}$ ise yerel yönetimlerin gelire olan gereksinimini arttırmaktadır. Ancak birçok gelişmiş ülkede bile yerel idarelerin harcamaları; çoğunlukla gelir paylaşım yöntemlerine, merkezi idareler tarafından kontrol edilen vergilere ve gelir transferlerine dayanmaktadır (Rodden, 2003:724). Merkezi devlet ve yerel yönetimler aynı kaynaktan gelir sağlamak

\footnotetext{
${ }^{3}$ Halen Türkiye'de belediye meclislerinin çalışma usul ve esasları ile görevleri 3/07/2005 tarihli ve 5393 sayll Belediye Kanununun 17-32 maddeleri arasinda, Büyükşehir belediyeleri meclisleriyle ilgili düzenlemeler ise 10/07/2004 tarihli ve 5216 sayılı Büyükşehir Belediyesi Kanununun 12-15'nci maddeleri arasında yer almaktadır. Belediye meclisi üyelerinin seçiminde, 26/4/1961 tarihli ve 298 sayılı Seçimlerin Temel Hükümleri ve Seçmen Kütükleri Hakkında Kanun ile 18/01/1984 tarihli ve 2972 sayılı Mahalli İdareler ile Mahalle Muhtarlıkları ve İhtiyar Heyetleri Seçimi Kanun hükümleri düzenlemeleri uygulanmaktadır.

${ }^{4}$ Örneğin Avusturya, Belçika, Almanya, Meksika, İspanya, Çek Cumhuriyeti ve İtalya gibi ülkelerde gelir paylaşımına iliş̧in düzenlemeler, bu Devletlerin Anayasalarında yer almaktadır (Blöchliger, 2006:12) .
} 
zorundadırlar. $\mathrm{Bu}$ kaynakta doğal olarak ülkenin milli geliridir (Keleş, 1972:60). Merkezi idare kamusal mal üretiminde ölçek ekonomilerinden faydalanmaktadır. Diğer taraftan, küreselleşmeyle beraber merkezi devlete yüklenen görev tanımında değişiklik olması ve devletin küçülmesi gerektiği yönündeki düşünce ve uygulamaların uzantısı olarak merkezi hükümetin birçok yetki ve gücünü uluslararası bölgesel kuruluşlara devrettiği ve ülke düzeyinde kamusal hizmetleri yerine getirecek kamu kuruluşu olarak yerel yönetimlerin ön plana çıktığı (Yüksel, 2007:290) yönünde yaklaşımlar da bulunmaktadır. Merkezi devlete düşen rol ise geleneksel mali federalizm kuramlarında olduğu gibi daha çok gelir dağılımının düzeltilmesi ya da savunma hizmeti gibi ulusal kamusal malların üretiminin sağlanmasıdır (Journard ve Kongsrud, 2003:168). Buradaki temel düşünce yerel yönetimlerin bireylere "daha yakın olması" ve onların gereksinimlerini daha yakından görebilmesidir. Bu seçmenlere daha fazla bilgi aktarımını sağlayacağından rant kollama ya da vergi ile harcama arasında kurulacak bağlantı dolayısıyla mali yanılsama gibi konuların azalmasına neden olabilecektir. Ancak bu yerel demokratik süreçler ve seçmenlere sunulan bilgilerin kalitesi ile de yakından ilgilidir (Rodden, 2003:701). Ayrıca yerel yönetimlere mali güç ve yetki devrinin artık yetersiz olduğu ileri sürülen "devlet baba" yerine "yerel baba" mantığına oturtulması tehlikesi de bulunabilmektedir 5 .

Konunun bir boyutu da vergi adaletiyle ilgilidir. Eğer iki yerel yönetim aynı miktar kamusal mal üretiminde bulunursa ancak bu bölgelerden birinde yaşayanlar diğerlerine göre daha refah içerisindeyse, diğer koşulların sabit olduğu varsayımıyla, bu bölgede yaşayanların tabi olacakları vergi oranları daha düşük olacaktır (Oates, 1968:46). Ancak bireylerin yerleşme yerlerini seçerken karşı karşıya kalacakları mali yükün aynı olması beklenmelidir. Örneğin ülkenin farklı bölgelerinde yaşayan aynı gelire/ servete sahip iki bireyden biri diğerinden daha fazla vergi ödememelidir (Buchanan, 1950:589,591). Ayrıca yerel idareler tarafindan uygulanan vergiler yanında, merkezi idarenin yerel idarelere yapmış olduğu transferler de bireylerin nerede yerleşecekleri ve nerede çalışacakları kararlarını etkilemektedir (Stiglitz, 2000:741). Yine küreselleşmenin merkezi idare lehine farklı etkileri olabilmektedir. Örneğin Avustralya, Çin ve İsviçre gibi bazı ülkelerde daha önce yerel idarelerin sorumluluğunda olan ciro ya da genel satış vergisi gibi bazı vergilerden vazgeçilerek merkezi idare tarafindan toplanan katma değer vergisi sistemine geçilmiştir. Ayrıca yaşlanan nüfusa sahip devletlerde, bu

\footnotetext{
${ }^{5}$ Falay, bu yaklaşımı yerel yönetimlere güç ve yetki devrinin halka daha fazla hizmet gitmesini ve halkın kendisini yönetmesini sağlayacağına olan yaygın kanıya istinaden gündeme getirmektedir (Falay, 1997:9).
} 
nedenden kaynaklanan kamu harcaması artışları, merkezi yönetim ile yerel yönetim arasında vergi geliri dağılımında, merkezi yönetim lehine olmak üzere etkide bulunmaktadır (Journard ve Kongsrud, 2003:169-70).

$\mathrm{Bu}$ çerçeve içerisinde Türkiye'de belediye meclislerinin vergilendirme yetkileriyle ilgili kurallar izleyen bölümlerde belirtilmiştir.

\subsection{Cumhuriyetin Başlangıcından 1981 Yılına Kadar Olan Dönem}

Cumhuriyet Döneminde yapılan çalışmalardan önce, bu dönemin temellerinin dayandığ 1 ve başlangıçta bu dönemin kurallarının uygulandığ 1 Osmanlı Devletinin yerel idarelere olan yaklaşımı konusunda kısa bir bilgi vermek faydalı olacaktır. 19. yüzyıla kadar Osmanlı Devletinde bazı hizmetler, mahalli gruplara, dini cemaatlere ve vakıflara bırakılmıştı. Tanzimat Döneminin idari reformları ise mahalli idarelerin doğuşu için gerekli reformları hazırlamıştı. Gerçi Tanzimat dönemi devlet adamları, siyasal katılma, mahalli demokrasi gibi bir siyasal program benimsememişlerdi ancak Matternich ${ }^{6}$ Avusturya'sını örnek almışlardı. Bu dönemde maliyenin ıslahı için vilayetlerde sancak merkezlerine gönderilen vali yetkisinde ancak validen bağımsız yüksek rütbeli maliye memurları diğer bir ifadeyle muhassıllar bulunacaktı ve bunların yanında muhassıl meclisleri kurulacaktı. Bu meclislerde muhassılın maiyet memurlarından başka, bölgenin hâkimi, müftüsü, askeri sabiti, ruhani liderleri ve ayrıca bölgenin ileri gelenlerinden altı kişi bulunmaktaydı (Ortayl, 1982:142). Gerek bölgenin ileri gelenlerinin seçim yöntemi gerek bu meclislerin çalışma yöntemleri birçok belirsizliği ve soru işaretlerini beraberinde taşısa da "Osmanlı İmparatorluğunun tarihinde ilk defa kurumsallaşan ve mahalli halkın temsilcilerinin katıldığı kurullardan bahsetmek mümkün bulunmaktadır ve bu ileri bir adımdır (Ortaylı, 1982:145)." Daha sonra Kanuni Esasi, belediye yönetiminin diğer bir ifadeyle "umuru belediye" nin belediye meclislerine bırakılacağını 112'nci maddesinde açıkça ifade etmiştir. Belediye meclisleri icrai-idari kararlar alabilen organlardır (Yayla, 1982:43). 1858'de İstanbul'da kurulan ilk belediye dairesi olan Altıncı Daire ile sonradan İstanbul'un diğer belediye daireleri halktan biri alelade diğer fevkalade iki tür vergi alabilmekteydi ${ }^{7}$. İlk belediye teşkilatının kurulmasından

${ }^{6}$ Ortaylı, ayrıca Matternich'in de Osmanlı reformlarını onayladığını ve izlediğini belirtiyor (Ortayl1, 1982:143).

${ }^{7}$ Alelade vergiler, umum için konulan kandillerden dolayı hane ve dükkânlardan tahsil olunan vergiler, sokakların idare ve bakımı için belediye meclisince icra olunacak her türlü 1slahat ve imalat için alınacak yıllık vergiler, her nevi mizan ve ölçü resim 
sonra belediyeler, İkinci Meşrutiyet Döneminden sonra İstanbul'un her tarafına yayılabilmişlerdir. İstanbul dışında başka şehirlerde ise belediye teşkilatı Birinci Meşrutiyet döneminde kabul edilen 1877 tarihli Vilayet Belediye Kanunu ile kurulmaya başlamıştır (Ergin, 1995:1265). Ancak belediyeler buna rağmen gelişememişlerdir. Bunda temel etken merkezi hükümet karşısında mahalli grupların iktisadi gücünün aynı oranda artmaması ve yerel idarelerin iktisadi ve buna bağlı olarak hukuki özerklik konusunda geri kalmalarıdır (Ortayl1, 1982:147).

Osmanlı Döneminin âdemi merkeziyet anlayışı, 1921 ve 1924 Anayasalarında da devam etmiştir (Güler: 2000:14). Cumhuriyetin ilk kurulduğu yıllarda belediyelerin gelirleri, 1914 y1lında uygulamaya giren Rüsum-u Belediye Kanununa dayanmaktadır. Daha sonra bu Yasada 1924 yılında 338 sayılı Kanunla ${ }^{8}$ değişiklik yapılmıştır. Aynı yıl ayrıca 423 sayılı Belediye Vergi ve Resimleri Kanunu uygulamaya girmiştir. Bu Kanun ile belediyelere bazı vergi ve resimleri toplama yetkisi yanında bazı vergi ve resimlerinde tutarını belirleme yetkisi verilmiştir (Çağan, 1982:55). Örneğin, belirlenmiş tavanı aşmamak kaydıyla belediye sınırları içerisinde tüketilen petrol ve benzin üzerinden istihlak resmi alma konusunda belediye meclisleri yetkili kılınmıştır (Küsmenoğlu: 2010:308). Bunun nedeni devletin mahalli işbölümünü değiştirmesidir (Reuter, 1943: 117). Daha sonra 1930 y1lında çıkarılan ve Fransa'nın 1884 tarihli Belediye Kanununun çeviriye yakın bir uygulamas1 olan (Duran, 1982: 152) 1530 sayıl1 Belediye Kanunu da bazı vergilerin tahsil yetkisini belediyelere vermiştir. Ancak belirtmek gerekir ki bu dönemde şehirlerin mali durumu hakkında yapılan bir çalışma yoktur ve bu oldukça ihmal edilen bir alandır 9 . Ayrıca bu dönemi, daha sonra kamu maliyesinde köklü değişimlere neden olacak Dünya Ekonomik Buhranın yaşandığ dönem olarak dikkate almak gerekmektedir. 1936 yılında bina, buhran ve arazi-yol vergileri mahalli idarelere bırakılmıştır (Aktan, 1974:106).

hasılatı, bina inşaası için verilecek ruhsat harcı ile tarifesine göre alınacak patent resminden oluşmaktaydı. Fevkalade vergiler ise açılacak ve inşa olunacak yeni yol ve lağımlar için hane ve dükkânlardan alınacak vergi ile Altıncı Daire sınırları içindeki emlakin vergilerinin \% 2'si oranında alınacak ek belediye resmi idi. Bkz. Öner, 2005:404.

${ }^{8} \mathrm{Bu}$ Yasa ile inşaat ve inşaat iskan ve ruhsatlarından belediyelere gelir sağlanması hedeflenmiştir.

${ }^{9}$ Ernst İstanbul Belediyesinin Mali Durumu (1937-1948) isimli çalışmasının sonunda bu durumu şöyle açıklamaktadır. "İstanbul Dünyanın en güzel şehridir. Fakat mali temel sağlam olmadan en büyük idare dehası bile bu şehri tabii güzelliğiyle mütenasip bir hale getiremez." (Ernst, 1948:489-503) 
Daha sonra 423 sayılı Yasanın yerine 1 Ağustos 1948'de 5237 sayılı Belediye Gelirleri Kanunu yürürlüğe girmiştir. Bu Yasada yaklaşık 44 adet gelir kaynağı bulunmaktadır. Buna karşılık bu kadar çok kaynağa dayanmasına rağmen, belediyelerin yeteri gelir kaynağı bulunmamaktadır (MB, 1989:22).

$\mathrm{Bu}$ dönemde yürürlükte olan 1924 Anayasasının vergilendirme ile 84'üncü maddesinde "vergi, Devletin genel giderleri için, halkın pay vermesi" olarak tanımlanmıştır. "Bu esaslara aykırı olarak gerçek veya tüzel kişiler tarafından veya onlar adına resimler, ondalık alınması ve başka yüklemeler yapılması yasaktır." 85'inci maddesinde ise "Vergiler ancak kanunla salınır ve alınır. Devletçe, illerin özel idarelerince ve belediyelerce alına gelmekte olan resimler ve yüklemeler, kanunları yapılıncaya kadar alınabilir." düzenlemesi yer almaktadır.

Buna karşı1ık 1948 yılında uygulama giren 5237 sayılı Yasanın çeşitli maddelerinde belediye meclislerine vergi, resim ve ücret belirleme yetkisi verdiği görülmektedir ${ }^{10} .5237$ sayılı Yasada yer alan bu düzenlemelerin 1924 Anayasasının yukarıda belirtilen 85'inci maddesi ile birlikte değerlendirildiğinde, öncelikle 85 'inci maddede yer alan düzenlemeye uygun bir şekilde bu vergi, resim ve harçların yasa ile düzenlendiğini belirtmek gerekiyor. Ancak vergi ve resmin harcın Yasada sadece tanımlanması ve maddede tutara ile ilişkin hiç bir belirleme yapılmamasının ve bu yetkinin belediye meclislerine bırakılmasının 85'inci madde ile örtüştüğünü iddia etmek doğru olmayacaktır. Diğer taraftan bu dönemde yasaların Anayasaya

\footnotetext{
${ }^{10}$ Bunlara örnek olarak şehirlerarası ve milletlerarası haberleşmeleri ayrık olmak üzere ayrık olmak üzere bütün telefon ve konuşma ücretlerine belediye meclisi kararı ile \% 20 nispetinde belediye payı eklenmesi (md.8), kiraya verilmeyen binalarda safi iradin $\%$ 2,5'i, kiraya verilen binalarda \% 5'ini ve iratlı arsalarda kıymetin binde beşini geçmemek üzere belediye meclisi kararı ile alınan temizletme ve aydınlatma resmi (md.9), hayvan kesim ücreti ve resminin belediye meclisi kararı ile yarısına kadar indirilebilmesi (md.10), et taşıma (md.11), balıkhane ücretlerinin (md.12) belediye meclislerince kararlaştırılması, iştirak paylarının kıymetlerinin \% 3 ile 6'sı arasında hesaplanan tutarlarına ait taksitlerinin ödeme zamanının belediye meclislerince belirlenmesi (md.13), harita ve imar planları iştirak payının (md. 14), nakil vasıtaları numara resminin (md. 17), kara nakil vasitaları resminin (md. 18), küçük deniz nakil vasıtaları resminin (md.19), iskele ve rıhtımlardan alınacak geçiş resminin (md. 20), ilan ve reklam resminin (md. 21), tellallık resmi (md.25), eğlence yerleri açılmasına ait ruhsat harcının (md.27), bilet kullanılması mecburi olmayan eğlence yerlerine ait eğlence resminin (md. 27) yer işgal resminin (md.28), kazan ve motörlerden alınacak resimin (md.29), akaryakıt resmi (md.30), kaynak sularından alınacak resimin (md.32) belediye meclislerince belirlenmesi örnek gösterilebilir. Yine tahsili isteğe bağlı olan süs köpekleri resmi (md 34), tente, siper ve saçak resmi (md. 35) belediye meclislerince belirlenmektedir.
} 
uygunluğu belirleyen Anayasa Mahkemesi ya da benzeri bir organ bulunmadığını vurgulamak da gerekmektedir.

5237 sayılı Yasanın uygulandığı dönemde, 1961 Anayasası yürürlüğe girmiştir. Vergi ile ilgili düzenlemeler, 1961 Anayasasının 61'inci maddesinde yer almış ve maddenin ilk hali "Herkes, kamu giderlerini karşılamak üzere, malî gücüne göre, vergi ödemekle yükümlüdür. Vergi, resim ve harçlar ve benzeri malî yükümler ancak kanunla konulur." şeklinde olmuştur. Daha sonra bu maddeye 1971 yılında11 "Kanunun belli ettiği yukarı ve aşağı hadler içinde kalmak, ölçü ve esaslara uygun olmak şartıyla, vergi, resim ve harçların muafiyet ve istisnalarıyla nispet ve hadlerine ilişkin hükümlerde değişiklik yapmaya, Bakanlar Kurulu yetkili kılınabilir.” paragrafı eklenmiştir. 1961 Anayasasının 116'ncı maddesi yerel idarelerin mali özerkliğiyle ilgili olarak “... bu idarelere görevleri ile orantılı gelir kaynakları sağlanır.” düzenlemesine yer vermiştir. Ancak bu gelirlerin hangi kaynaklardan sağlanacağı Anayasada belirtilmemiştir (Çağan, 1980:136). Üstelik 1961 Anayasasının 116.maddesindeki buyruğunun savsaklandığı, belediyelerin devlete avuç açar duruma geldiği belirtilmektedir (Geray, 1977:45). Bu dönem aynı zamanda Türkiye'de kalkınma programlarının uygulanmaya başlandığı dönemdir ve merkezi idare yanında yerel yönetimlerinde idari yapılanmalarında değişikliğe gidilmiştir. $\mathrm{Bu}$ dönemde, belediyeler gittikçe artan bir hizmet yükü altına girdikleri halde vergi kaynakları adil olarak bölüşülmemiş, belediyelere bırakılmış olan vergilerin matrah ve oranları da yetersiz kalmıştır (Keleş, 1972:67-68.).

Daha sonra yürürlüğe giren 1982 Anayasasında, 1961 Anayasasının genel sistematiğini korunmakla birlikte 73'üncü maddeye ayrıca "Vergi yükünün adaletli ve dengeli dağılımı, maliye politikasının sosyal amacıdır." ibaresini taşıyan ikinci paragraf eklenmiştir. 5237 sayılı Belediye Gelirleri Kanununun bazı hükümleri, 1924 Anayasasının uygulandığı dönemden farklı olarak 1961 Anayasası döneminde iptal edilmiştir (Çağan, 1982: 56 ve ayrıca Gerek ve Aydın, 2005:386-97). Ancak iptal kararlarında belediye meclislerinin bu yetkiye sahip olması değil, belediye meclislerine tanınan yetkilerin muğlak ve sınırsız olması durumları irdelenmiştir. verilebilir.

$\mathrm{Bu}$ iptal edilen düzenlemelere ilişkin olarak aşağıdaki örnekler

a) Levhalardan Alınan Resim Konusunda Belediye Meclislerine Tanınan Yetkinin İptali

\footnotetext{
1120.9.1971 tarihli ve 1488 sayılı Yasa
} 
5237 say1l1 Belediye Gelirleri Kanununun 21'inci maddesinin üçüncü fikrasinda yer alan "Bu levhalardan Belediye Meclislerince düzenlenecek tarifeye göre yıllık bir resim alınır" hükmüyle ilgili olarak Anayasa Mahkemesi resim tutarlarının belediye meclislerince belirlenmesi dolayısıyla 29.3.1966 tarihli ve E.1965/45, K: "1966/16 say1lı Kararında yasama yetkisinin devredilemeyeceği gerekçesiyle iptal kararı vermiştir ${ }^{12}$. Kararda yer alan gerekçe aşağıdaki gibidir:

"5237 sayılı Kanunun 21 inci maddesinin birinci fikrası ve üçüncü fikrasının iptali istenilen hükmü ile levha resminin konusu ve mükellefleri gösterilmiştir. Buna karşılık, iptali istenilen hükümde bu resim hakkında bir matrah ve oran ya da azami bir miktar konulmamış, bu resim belediye meclislerince düzenlenecek tarifeye göre alınacağı açıklanmıştır. Tarifenin düzenlenmesinde belediye meclisleri tamamen serbest bırakıldıklarından resim miktarının tayini bu meclislerin takdirine bırakılmış demektir. Belediye meclislerinin bu serbestliğe dayanarak aşırı derecede yüksek levha resimleri tarh ettikleri ve hata tarife kavramını kendi anlayışlarına göre yorumlayarak aynı tarifede levha resimlerinin, bir kısım mükellefler için binaların gayrisafi iradının bir oranı üzerinden ve başka mükellefler için sübjektif ve kişisel takdire göre alındığı 9 uncu dairenin kararından anlaşılmaktadır. Böylece, malî yükümlerde, idareye sınırsız bir yetki verilmesinden doğabilecek sakıncalar levha resminde gerçekleşmiş bulunmaktadır. Hükümet keyfi uygulamaları önlemek istemiş ve 5237 sayılı Kanunun tasarısına ait gerekçesinde, daha önce belediye meclislerinin takdirine bırakılmış olan levha resmi miktarının 400 lirayı geçemeyeceğini belirtmiş ve tasarının 19 uncu maddesine de (Yürürlükteki 21 inci madde) bu yolda hüküm koymuştur. Fakat bu tavan kanunda yer almamış ve yürürlükte bulunan, sınırsız ve keyfi uygulamalara elverişli metin kabul olunmuştur.

Bu durum karşısında, malî yükümler konusu yukarıda genel olarak incelenirken açıklanan nedenlerle, levha resminin kanunla konulmuş sayılamayacağı ve iptali istenilen hükmün bundan ötürü Anayasa'nın 61 inci maddesin ikinci fikrasına aykırı olduğundan iptal edilmesi gerektiği kabul olunmalıdır.”

b)İlan ve Reklamlardan Alınacak Resim Konusunda Belediye Meclislerine Tanınan Yetkinin İptali

5237 say1lı Belediye Gelirleri Kanununun 21'inci maddesinin dördüncü fikrasinda yer alan "Her ne suretle ve vasita ile olursa olsun yapllacak diğer ilân ve reklâmlardan Belediye meclislerince düzenlenecek esas ve tarifelere göre resim alınır" hükmüyle ilgili olarak Anayasa Mahkemesi resim tutarlarının belediye meclislerince belirlenmesi dolayısıyla 3.7.1969 tarihli ve

${ }^{12} \mathrm{RG}: 12.5 .1966 / 12297$ 
E.1969/23, K: “1969/41 sayılı Kararında, yasama yetkisinin devredilemeyeceği gerekçesiyle iptal kararı vermiştir ${ }^{13}$. Kararda yer alan gerekçe aşağıdaki gibidir:

“..5237 sayılı Kanunun 21. maddesinin dördüncü fikrasının iptali îstenen hükmünde malî yükümün, konusu ve yükümlüleri gösterilmiş, fakat, matrahı, oranı veya en çok miktarı gösterilmemiş, ilân resminin belediye meclislerince düzenlenecek tarifeye göre alınacağının açıklanması ile yetinilmiştir. Tarifenin düzenlenmesinde belediye meclisleri, kanunun bir sınır tanımamış olmasından yararlanarak diledikleri gibi resim alınmasını öngörecekler, böylece idareye, malî yüküm bakımından, sınırsız yetki tanınmasından doğabilecek sakıncalar gerçekleşmiş olacaktır. Nitekim itirazla ilgili olayda 9257,88 lira ilân resmî tahakkuk ettirilmiş bulunmaktadır.

Bu nedenlerle, iptali istenilen hükmün Anayasa'nın 61. maddesine aykırı olduğu açıkça görülmektedir."

c) Diğer Reklamlardan Alınacak Resim Konusunda Belediye Meclislerine Tanınan Yetkinin İptali

5237 say1lı Belediye Gelirleri Kanununun 21'inci maddesinin dördüncü fikrasinda yer alan "'her ne suretle ve vasita ile olursa olsan yapılacak diğer reklamlardan belediye meclislerince düzenlenecek esas ve tarifelere göre resim alınır."” hükmüyle ilgili olarak Anayasa Mahkemesi resim tutarlarının belediye meclislerince belirlenmesi dolayısıyla 22.12.1970 tarihli ve E.1970/29, K: "1970/48 sayılı Kararında Belediye Meclisine tanınan yetkinin malî yüküm kavramıyla bağdaşmayacak sınırsız bir yetki olduğu belirtilmektedir ${ }^{14}$. Kararda yer alan gerekçe aşağıdaki gibidir:

“5237 sayılı Kanunun 21. maddesinin dördüncü fikrasının iptali istenen hükmünde malî yükümün konusu ve yükümlüleri gösterilmiştir. Ancak matraha, orana veya en yüksek sınıra ilişkin hiç bir saptama yoktur. Fıkrada reklam resminin belediye meclislerince düzenlenecek esas ve tarifelere göre alınacağının açıklanması ile yetinilmiştir. $\mathrm{Bu}$, malî yüküm kavramiyle bağdaşmayacak sınırsız bir yetkidir. Yukarıdan beri açıklananlardan anlaşılacağı üzere itiraz konusu hükmün Anayasa'nın 61. maddesine aykırı olduğu ortadadır; iptali gerekir."

\subsection{Yılından Sonraki Dönem}

1960'lı yılların sonuna doğru yeni idari yapılanma ve belediyelerin artan önemi dikkate alınarak İçişleri ve Maliye Bakanlıkları tarafından Belediye

\footnotetext{
${ }^{13} \mathrm{RG}: 7.2 .1970 / 13420$
}

${ }^{14} \mathrm{RG}: 18.4 .1971 / 13813$ 
Kanunu, Belediye Gelirleri Kanunu, Özel İdareler Maliyesi Reformu Kanunu, Mali Tevzin Kanunu ve Emlak Kanunu tasarıları hazırlanmış ancak 1970 yılında yasalaşan 1319 sayılı Emlak Vergisi Kanunu dışında diğer tasarılar, yasalaşamamıştır.

Sanayileşme politikaları sonucunda köyden kente göçlerin artması ile birlikte kent nüfuslarının ve buna bağlı olarak yerel yönetimlerden hizmet beklentilerinin artmas1, yerel idarelerin gelir kaynaklarına olan gereksinimini arttırmıştır. 1975-2005 döneminde, faiz dışı kamu harcamaları içerisinde belediyelerin payı üç kat artarak \% 12,3 düzeyine yükselmiştir. Belediyeler, 1948 yılından 1981 yılına kadar gelirlerini önemli ölçüde 5237 sayılı Yasaya dayanarak elde etmişlerdir. Daha sonra 5237 sayılı Yasanın yürürlüğe girdiği döneme ait Türkiye'nin iktisadi yapısı ve koşullarının değişmesi dikkate alınarak yeni bir belediye gelirleri yasası hazırlanmıştır. Ancak 1978 yılında içerisinde Belediye Gelirleri tasarısının da bulunduğu vergi paketi tasarısı, mecliste kabul edilememiştir ${ }^{15}$. 2464 sayılı Belediye Gelirleri Kanunu, daha sonra 1 Temmuz 1981 yılında uygulamaya girmiştir ${ }^{16}$. 2464 sayılı Yasa, belediye sınırları ve mücavir alan içerisinde uygulanmaktadır. Bu yasa ile eski vergiler arttırılmış, yeni vergi ve harçlar getirilmiştir. Genel olarak belediye kaynakları genişletilirken, merkezi idarenin bu kaynakların kullanımına ilişkin tespit yetkisi de genişletilmiştir (Kumrulu 1988:230). Bu Yasanın ruhunda, kentte yaşayan kent halkından, kent hizmetlerinden yararlananların, bu bedeli parasal olarak ödemeleri ilkesi temel alınmıştır (Tezesen ve Ağaçl1, 1995:258). Yasada tanımlanan bazı gelirler doğrudan belediyeler tarafindan tahsil edilirken bazı gelirler diğer idareler tarafindan tahsil edilip belediyelere aktarılmaktadır. Bu kapsamda örneğin ilan ve reklam vergisi, eğlence vergisi ile çevre temizlik vergisi doğrudan belediyeler tarafindan elektrik ve hava gazı tüketim vergisi, yangın sigortası vergisi diğer kurumlar tarafindan tahsil edilip belediyeye aktarılmaktadır (Öner, 2012:441). 2464 sayılı Yasa gerekçesinde vergi, harçlar ve harcamalara katılma payları olmak üzere üç temel esastan hareket edilerek köklü ve sistemli şekilde hazırlandığı belirtilmekle birlikte 2464 sayılı Yasa, temel itibariyle bir önceki Yasadan farklı hazırlanmamıștır. Diğer taraftan yasalaşma yöntemi ve tarihi, daha sonra belirtileceği üzere, 2464 sayılı Yasaya Anayasa Mahkemesi karşısında önemli bir ayrıcalık sağlayacaktır. Bu dönemde

${ }^{15}$ Kumrulu, bu durumu şöyle açıklamaktadır: “... 1978'de Ecevit hükümeti vergi paketi parlamentoda engellenmiştir. Belediye Gelirleri tasarısı da bu pakette yer alıyordu. Daha sonra Demirel hükümeti ayni Belediye Gelirleri tasarısını meclise sevk etmiştir." (Kumrulu, 1988:198-99).

16Yasanın 106'ıncı maddesine göre Temizleme ve Aydınlatma Harcı ile ilgili 45 ila 51 inci madde hükümleri, Emlak Vergisi 1980 genel beyan dönemini izleyen ilk genel beyan döneminin rastladığı bütçe yılının başında yürürlüğe girmiştir. 
ayrica 3239 sayıl1 Yasa ile 1.1.1986 tarihinden itibaren emlak vergisinin tarh, tebliğ, tahakkuk ve tahsil işlemleri belediyelere bırakılmıştır.

2464 sayılı Belediye Gelirleri Kanununda vergi ve harç tutar ve oranlarının tespiti konusunda üçlü bir uygulama söz konusudur. Bunlar aşağıdaki gibidir.

-Bazı vergilerin oranları doğrudan Yasada belirlenmiştir.

- Bazı vergi ve harç tarifeleri, Yasada belirtilen en az ve en çok tutarları arasında Bakanlar Kurulunca belediye grupları itibariyle farklı olarak tespit edilmektedir. $\mathrm{Bu}$ amaçla belediyeler, nüfusları ve ekonomik göstergeleri itibariyle beș gruba ayrılmakta ve bu gruplar Resmi Gazetede ilan edilmektedir (md.96/A). Bunlar Kaynak Sular1 Harc1, ayvan Kesimi Muayene ve Denetleme Harcı, Ölçü ve Tartı Aletleri Muayene Harc1, Kayıt ve Suret Harc1, İmar Mevzuatı Gereğince Alınacak Harçlar, (Ticaret ve konut bölgeleri için ayrı ayrı), Muayene, Ruhsat ve Rapor Harcı, Sağlık Belgesi Harcı ve Bina İnşaat Harcıdır.

-Bazı vergi ve harçların maktu tarifeleri; Yasada belirtilen en alt ve en üst sınırları aşmamak şartıyla mahallin çeşitli semtleri arasındaki sosyal ve ekonomik farkl1lıklar göz önünde tutularak belediye meclislerince tespit olunmaktadır (md. 96/B).

$\mathrm{Bu}$ noktada temel bir ayrım, oran olarak (advolorem) belirlenen vergilerin yasada açıkça tanımlandığı buna karşılık tutar olarak belirlenenler konusunda Bakanlar Kuruluna ya da belediye meclislerine yetki verildiği şeklinde yapılabilir. 2464 sayılı Belediye Gelirleri Kanununda yer alan vergi, resim ve harçların belirlenme yöntemleri Tablo 1'de verilmiştir. 
- Ankara Üniversitesi SBF Dergisi • 67-4

Tablo 1 : Vergilerin Belediye Gelirleri Kanununa göre Belirlenme Yöntemleri

\begin{tabular}{|c|c|c|}
\hline Vergi Türü & $\begin{array}{c}\text { Verginin Belirlenme } \\
\text { Yöntemi }\end{array}$ & $\begin{array}{l}\text { Vergi } \\
\text { Oran/Tutar } \\
\text { Maddesi }\end{array}$ \\
\hline İlan ve reklam vergisi (md.12-16) & Belediye meclisi & md.15 \\
\hline Eğlence vergisi (md.17-22) & $\begin{array}{l}\text { Biletle girilmesi zorunlu } \\
\text { olmayan yerlerde verginin } \\
\text { matrahını belediye meclisi } \\
\text { belirler }\end{array}$ & $\begin{array}{c}\mathrm{md} .20 / 3, \mathrm{md} \\
21\end{array}$ \\
\hline Haberleşme vergisi ( md.29-33) & Yasa $(\% 1)$ & md.32 \\
\hline Elektrik ve havagazı tüketim vergisi (md.34-39) & Yasa (\% 1 ile $\% 5)$ & md.38 \\
\hline Yangın ve sigorta vergisi ( md.40-44) & Yasa $(\% 10)$ & $\mathrm{md} .43$ \\
\hline Çevre temizlik vergisi (md.44) & BKK, belediye meclisi & md. 44 \\
\hline İşgal harcı ( md.52-57) & Belediye meclisi & md.56 \\
\hline Tatil günlerinde çalışma ruhsatı harcı (md.58-62) & $\begin{array}{l}\text { Belediye meclisi ( } 20 \text { TL- } \\
800 \mathrm{TL})\end{array}$ & md.60 \\
\hline Kaynak suları harc1 (md. 63-66) & BKK & md.65 \\
\hline Tellallık harcı (md.67-71) & $\% 1$ & $\operatorname{md} .70$ \\
\hline $\begin{array}{l}\text { Hayvan kesimi ve muayene denetleme harc1 } \\
\text { (md.72-75) }\end{array}$ & BKK & md.74 \\
\hline Ölçü ve Tartı Aletleri Muayene Harcı (md.76- 78) & BKK & md.77 \\
\hline Bina inşaat harc1 (ek md. 1-6) & BKK & Ek md.6 \\
\hline Kayıt ve suret harc1 ( md.79) & BKK & md.84 \\
\hline İmar ile ilgili harçlar (md. 80) & BKK & md.84 \\
\hline \multicolumn{3}{|l|}{ İşyeri açma izni harcı (md. 81) } \\
\hline Muayene, ruhsat ve rapor harc1 (md.82) & BKK & md.84 \\
\hline Sağlık belgesi harcı (md.83) & BKK & md.84 \\
\hline Yol harcamalarına katılma payı ( md.86) & $\begin{array}{l}\text { Vergi değerinin \% 2'sini } \\
\text { geçemez }\end{array}$ & md.89 \\
\hline $\begin{array}{l}\text { Kanalizasyon harcamalarına katılma payı (md. } \\
\text { 87) }\end{array}$ & $\begin{array}{l}\text { Vergi değerinin \% 2'sini } \\
\text { geçemez }\end{array}$ & md.89 \\
\hline Su tesisleri harcamalarına katılma payı (md. 88) & $\begin{array}{l}\text { Vergi değerinin \% 2'sini } \\
\text { geçemez }\end{array}$ & md.89 \\
\hline
\end{tabular}

Belediye Gelirleri Kanunu'nun 65, 74, 77, 84 ve ek 6 nc1 maddelerinde belirlenen maktu harç tarifeleri, belediye grupları itibarıla son olarak 13.04.2005 tarihli ve 2005/8730 sayılı BKK ile belirlenmiştir. Yasanın 44'üncü 
maddesinde yer alan bina gruplarının tespiti ise 2005/9817 sayılı $\mathrm{BKK}^{17}$ ile belirlenmiştir. Diğer taraftan, 1992 yılında Bakanlar Kuruluna tanınan yetkinin tamamının kullanılmış olması dolayısıyla 2464 sayılı Yasada yer alan maktu tutarlar 2005 yılına kadar arttırılamamış, bu da belediyeler açısından önemli gelir sorunlarına neden olmuştur. Daha sonra Yeni Türk Lirasına geçerken, Yasada yer alan maktu tutarlar, bu yıllarda geçerli enflasyon ve yeniden değerleme oranları dikkate alınarak güncelleştirilmiştir.

Türkiye'de yerel idareler ile merkezi idareler aynı vergi matrahı üzerinden benzer vergiler almamaktadırlar ${ }^{18}$. Ancak halen belediyeler, Belediye Gelirleri Kanunu kapsamında topladıkları vergiler yanında, merkezi idare tarafından toplanan vergilerin sonradan idareler arasında paylaştırılması yaklaşımı içerisinde (2.2.1981 tarihli ve 2380 sayılı Belediyelere ve İl Özel İdarelerine Genel Bütçe Vergi Gelirlerinden Pay Verilmesi Hakkında Kanunun yerine) 2008 y1lında uygulamaya giren 5779 sayılı İl Özel İdarelerine ve Belediyelere Genel Bütçe Vergi Gelirlerinden Pay Verilmesi Hakkında Kanunda yer alan ilkeler çerçevesinde genel bütçe vergi gelirlerinden pay almaktadırlar. Bazı ülkelerde gelir paylaşımına ilişkin yöntemin (formülün) belirlenmesinde ulusal parlamentodan başka ayrıca federe devletlerinde onayına gereksinim bulunmaktadır. Bu ülkelere, paylaşım formülü her dört yılda bir yenilenen Avustralya ve Avusturya örnek olarak gösterilebilir (Blöchliger, ve Rabesona, 2009:11). Türkiye'de ise bu oran, sadece TBMM tarafindan belirlenmektedir.

2464 sayılı Yasanın daha önceki 1.7.1948 tarihli ve 5237 sayılı Belediye Gelirleri Kanununda yer alan belediye meclislerine vergi tutarların belirleme yetkisini geniş kapsamlı olmamakla birlikte sürdürmesi, 1982 Anayasasının 73'üncü maddesi ile birlikte değerlendirildiğinde, bu yetkinin Anayasaya uygun olup olmadığı tartışmalarını beraberinde getirmiştir. Örneğin bazı kaynaklarda Anayasa Mahkemesinin 1961 Anayasasında da yerel idarelerin vergilendirme yetkisine ilişkin bir hüküm bulunmamasına rağmen belirli alt ve üst sınırlar içerisinde bulunmak koşuluyla belediye meclislerinin aynı Bakanlar Kurulu gibi bu yetkiye sahip olduğunu kabul ettiği belirtilmektedir (Öncel vd., 2011:39). Ancak bu konuda genel kabul gören görüş, 1971 yılında Anayasaya eklenen ve 1982 Anayasasında da benimsenen Bakanlar Kuruluna Yasada belirtilen sınırlar içerisinde vergi tutarını belirleme yetkisi dışında herhangi bir

\footnotetext{
${ }^{17}$ RG: $26.05 .2005 / 26035$

${ }^{18}$ Örneğin eyalet sisteminin uygulandığı devletlerde, hem federal devlet hem de federe devlet , aynı vergi yükümlüsünden ayrı ayrı gelir vergisi toplayabilmektedir.
} 
merciin - ve belediye meclislerinin - bu yetkiye sahip olmasının Anayasaya aykırı olduğu (Öncel vd., 2011:39 ve ayrıca Çağan, 1984:177) yönündedir ${ }^{19}$.

\section{Anayasa Mahkemesinin Belediye Meclislerinin Vergilendirme Yetkisine İlişkin Kararı}

İhtirazi kayıtla verilen ilan ve reklam vergisi beyannamesi üzerinden tahsil edilen ilan ve reklam vergisinin ret ve iadesi istemiyle açılan davayla ilgili olarak Danıştay Vergi Dava Daireleri Kurulunca 26.5.1981 günlü, 2464 sayı11 Belediye Gelirleri Kanunu'nun 96. maddesinin (B) fikrasının iptaline karar verilmesi istemine ilişkin olarak Anayasa Mahkemesine yapılan başvuru sonucunda, Anayasa Mahkemesi, 29.12. 2011 tarihli ve E: 2010/62 ve K: 2011/175 sayılı Kararında ${ }^{20}$, söz konusu kuralın Anayasa aykırı olduğuna ve iptaline karar vermiştir. Anayasa Mahkemesi söz konusu Kararında, iptal gerekçesini aşağıdaki gibi belirtmiştir.

"Bireylerin sosyal ve ekonomik durumlarını etkileyecek keyfi uygulamalara neden olmaması için, vergilendirmede, vergiyi doğuran olayın ve vergilerin matrah ve oranlarının, yukarı ve aşağı sınırlarının, tarh ve tahakkuklarının, tahsil usullerinin, yaptırımlarının ve zamanaşımı gibi belli başlı temel ögelerinin kanunlarla belirlenmesi gerekir. Ancak, kanun ile her konuyu bütün kapsam ve ayrıntılarıyla düzenlemenin olanaklı bulunmadığ 1 durumlarda çerçevesi çizilerek bu sınırlar içinde kalmak koşuluyla uygulamaya ilişkin konularda yürütme organına açılayıcı ve tamamlayıcı nitelikte düzenleyici idarî işlem yapma yetkisi verilebilir.

İtiraz konusu kuralda, belediye gelirleri arasında yer alan bazı vergilerin maktu tarifelerini, kanunda belirlenen alt ve üst sinırlar arasında kalmak kaydiyla belirleme yetkisi belediye meclislerine verilmiştir. Belediye meclislerine verilen bu yetki, kanun koyucu tarafindan vergilemenin temel ögelerinin belirlenerek uygulamaya, tekniğe ve uzmanlığa ilişkin konularda yürütme organına verilen düzenleyici idari işlemlerde bulunma yetkisi ya da kanunla getirilen bir

${ }^{19}$ TBMM dışında vergi kararı almayla ilgili bir özellikli durum 18/3/1924 tarihli ve 442 sayılı Kanununun 1939 yılında değiştirilen 16'ncı maddesine göre en yüksek haddi yirmi lirayı aşmamak üzere herkesin hal ve vaktine göre köy ihtiyar meclisi kararıyla köyde oturanlara ve köyde maddi alakası bulunanlara salma salınabilmesiyle ilgilidir. Salma, geniş anlamda vergi olarak değerlendirildiğinde, alınmasına yasada belirlenen üst limit içerisinde köy ihtiyar meclisi karar vermektedir. $\mathrm{Bu}$ durumda, bu düzenlemenin Anayasaya aykırı olması gerekir. Ancak Anayasa Mahkemesi, 5/1/1965 tarihli ve E: 1963/198, K:1965/1 sayılı Kararında, Köy Kanununun 16’nc1 maddesinin Anayasaya aykırı olmadığına karar vermiştir.

${ }^{20}$ RG: $19.05 .2012 / 28297$ 
düzenlemeyi açılayıcı ve tamamlayıcı nitelikte verilen bir yetki olmayıp doğrudan vergi miktarının belirlenmesine ilişkin bir yetkidir.

Anayasa'nın 73. maddesinin dördüncü fikrasında, "vergi, resim, harç ve benzeri yükümlülüklerin muaflık, istisnalar ve indirimleriyle oranlarına ilişkin hükümlerinde kanunun belirttiği yukarı ve aşağı sınırlar içinde değişiklik yapmak yetkisi Bakanlar Kuruluna verilebilir" denilmektedir. Buna göre, Bakanlar Kurulu, yasanın belirttiği alt ve üst sınırlar içinde değişiklik yapabilecek, ancak bu sınırları aşacak biçimde herhangi bir düzenleme getiremeyecektir. Bakanlar Kurulu'na verilen bu yetki istisnai bir yetkidir. Vergilendirmede esas kural, vergilerin kanunla konulup, kaldırılması ve değiştirilmesidir. Dolayısıyla bu konularda yukarı ve aşağı sınırları belirleme yetkisi kanun koyucuya aittir. Bu sınırlar içinde değişiklik yapma yetkisi ise kanunun öngörmesi koşuluyla ancak Bakanlar Kurulu'na verilebilir.

$\mathrm{Bu}$ nedenle, belediye meclislerine vergi tarifesini belirleme yetkisi veren kural Anayasa'nın 73. maddesine aykırıdır. İptali gerekir.”

Anayasa Mahkemesinin Kararı, Resmi Gazetede yayımlandıktan bir y1l sonra diğer bir ifadeyle 19 Mayıs 2013 günü yürürlüğe girecektir.

\section{Anayasa Mahkemesinin Kararının Değerlendirilmesi}

5237 say1l Belediye Gelirleri Kanununun 21'nci maddesinde ilan ve reklam resminin belediye meclislerince düzenlenecek tarifeye göre y1llık bir

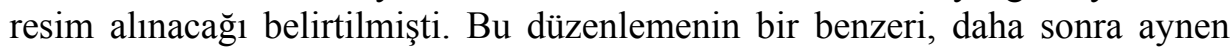
2464 sayılı Yasanın 12-16'ncı maddelerinde yer almıştır. Yukarıda örnekleri verildiği üzere, o tarihlerde henüz yeni kurulmuş olan Anayasa Mahkemesi 29.3.1966 tarihli ve E.1965/45 say1l1, 3.7.1969 tarihli ve E.1969/23 say1l ve 22.12.1970 tarihli ve E.1970/29 sayıl Kararlarında belediye meclislerine tanınan vergilendirme yetkisinin iptali yönünde kararlar vermiştir. Anayasa Mahkemesi bu kararlarında Yasada belediye meclislerine tanınan yetkide (üst) sınır olmadığı gerekçesine dayanarak iptal kararlarına vermiştir. Bu bağlamda, 2464 sayılı Yasanın 96' ınc maddesinde yer alan "Yasada belirtilen en alt ve en üst sınırları aşmamak şartıyla mahallin çeşitli semtleri arasındaki sosyal ve ekonomik farkl1lıklar göz önünde tutularak belediye meclislerince tespit olunur" düzenlemesinin, Anayasa Mahkemesinin vermiş olduğu bu iptal kararlarında yer alan gerekçelerin dikkate alınarak hazırlandığını göstermektedir. Buna karşılık 2464 sayılı Yasanın 21'nci maddesinde yer alan yetkiyle ilgili olarak verilen Anayasa Mahkemesi Kararında ise Belediye Meclislerinin alt ve üst sınırlar belirtilmiş olsa bile böyle bir yetkiye sahip olup olmadıkları sorgulanmış ve olmadığı sonucuna varılmıștır. 2464 sayılı Yasanın yürürlüğe girmesinden yaklaşık otuz yı1l sonra Anayasa Mahkemesinin vermiş 
olduğu bu Kararın geç kalınmış bir karar olduğu söylenebilir. Çünkü Anayasanın egemenliği kullanmaya yetkili kıldığı organlardan birisi, kendisine ait bir yetkiyi kullanma olanağını diğerlerine verememelidir ${ }^{21}$. Ancak burada vurgulanması gereken özel bir durum bulunmaktadır. 2464 sayılı Yasa, 29 Mayıs 1981 günlü ve 17354 sayılı Resmi Gazetede yayımlanmışı ve 1982 Anayasasının Geçici 15 'nci maddesi dikkate alındığında ${ }^{22}$, 12.9.19807.12.1983 tarihleri arasında çıkarılan yasalarla KHK'lerin ve 2324 sayılı Yasa uyarınca alınan karar ve tasarrufların Anayasa aykırılığı iddia edilememekteydi23. Örneğin Anayasa Mahkemesi 12/9/1991 tarihli ve E: 1991/31 ve K: 1991/27 sayılı Kararında "Anayasa, geçici 15. maddesi ile bir dönemin yasal işlemlerinin Anayasa'ya aykırıllı̆ı savında bulunulmasını uygun görmemiş, bir anlamda yasaklamıştır. ${ }^{24}$ " görüşündedir. Ancak Geçici 15 'nci maddenin halk oylaması sonucunda kabul edilen 12/9/2010 tarihli ve 5982

${ }^{21}$ Okandan, bu durumu şöyle açıklamaktadır: “... Mesela, yasama organı, Anayasanın kendisine verdiği yasama yetkisini başka bir organa devredemez. Aksi halde, lehine devir vuku bulan organ Anayasanın kendisine verdiği bir yetkiyi değil, yasama organının sağladığı bir salahiyeti kullanmış olur ki, bu durumun Anayasaya uygun olduğu söylenemez." Okandan, 1976: 451.

${ }^{22} 1982$ Anayasanın Geçici 15'nci maddesi şöyleydi: “12 Eylül 1980 tarihinden, ilk genel seçimler sonucu toplanacak Türkiye Büyük Millet Meclisi'nin Başkanlık Divanı oluşturuluncaya kadar geçecek süre içerisinde, yasama ve yürütme yetkilerini Türk Milleti adına kullanan, 2356 sayılı Kanunla kurulu Milli Güvenlik Konseyi'nin, bu Konseyin yönetimi döneminde kurulmuş hükümetlerin, 2485 sayılı Kurucu Meclis Hakkında Kanunla görev ifa eden Danışma Meclisinin her türlü karar ve tasarruflarından dolayı haklarında cezai, mali ve hukuki sorumluluk iddiası ileri sürülemez ve bu maksatla herhangi bir yargı merciine başvurulamaz. Bu Karar ve tasarrufların idarece veya yetkili kılınmış organ, merci ve görevlilerce uygulanmasindan dolayı, karar alanlar, tasarrufta bulunanlar ve uygulayanlar hakkında da yukarıdaki fikra hükümleri uygulanır."

23“12.9.1980-7.12.1983 tarihleri arasındaki dönemde çeşitli alanlarda 838 yasama işlemi, (669 yasa, 90 KHK ile 2364 sayılı Yasa uyarınca çıkarılmış MGK'nın 76 kararı ve 3 bildirisi) yapılmıştır. Anayasanın geçici 15'nci maddesi bu işlemlerin Anayasaya aykırılığı iddiasını yasaklamaktadır." (Tan, 1994:378)

${ }^{24} 2918$ sayılı Karayolları Trafik Kanunu ile ilgili bu karar da Anayasa Mahkemesi şu ibarelere yer vermiştir: “.. itiraz konusu kuralın Milli Güvenlik Konseyi'nin yönetimi döneminde çıkarılmış yasa kuralı olma niteliğini yitirmediği görülmektedir. ... Bu durumda, söz konusu kural hakkında, Anayasa Mahkemesi'ne başvurulmasına Anayasa'nın geçici 15. maddesi olanak vermediğinden itirazın, başvuran Mahkemenin yetkisizliği nedeniyle reddi gerekir." 
sayılı Yasanın 24'üncü maddesi ile ${ }^{25}$ kaldırılması sonucunda Anayasa Mahkemesinin belediye meclislerinin vergilendirme yetkisini değerlendirme olanağına sahip olduğunu ve Kararın bu Anayasa değişikliğinden sonra verildiğini dikkate almak gerekmektedir.

Belediye meclislerinin vergilendirme yetkisine sahip olup olmaması konusunun daha önce belirtildiği üzere siyasi, hukuki ve iktisadi boyutları bulunmaktadır. Konu yerel idarelerin mali özerkliği ile ilgilidir. Bu bağlamda mali anayasa tartışmalarının bir alt başlığı da mali federalim anayasasıdır (Leba: 2001:56). Ancak Anayasa Mahkemesi, yerel yönetimlerin özerkliği konusunda en azından şimdilik 1982 Anayasasının uygulama alanını belirlemiş olmaktadır. Diğer taraftan 2464 sayılı Yasanın yerine 2005 yılında köklü değişiklikler içeren yeni bir Belediye Gelirleri Kanunu taslağı hazırlanmış, ancak söz konusu Tasarısı yasalaş(a)mamıştır ${ }^{26}$.

Konunun farklı bir boyutu ise Avrupa Yerel Yönetimler Özerklik Şartı ${ }^{27}$ ile ilgilidir. Şart, Avrupa Konseyi bünyesinde 1988 yılında yürürlüğe girmiş, Türkiye ise 20.09.1988 tarih ve 13296 sayılı Bakanlar Kurulu Kararı tanınan yetki çerçevesinde 21.11.1988 tarihinde sözleşme olarak imzalamış ve 3723 say1lı Yasa ${ }^{28}$ ile onaylanması uygun görülmüs ve daha sonra 6 Ağustos1992 tarihli ve 92/3398 sayılı BKK ile onaylanarak ${ }^{29}$ bazı çekinceleriyle birlikte ${ }^{30} 1$ Nisan 1993'te yürürlüğe girmiştir. İdari alanda Türkiye'nin taraf olduğu en önemli uluslararası anlaşma olarak kabul edilebilecek (Muratlığlu, 2011:741). Sözleşmenin 9'uncu maddesi "Yerel Makamların Mali Kaynakları" başlığını taşımaktadır. Bu maddenin ilk üç fikrası şöyledir: "1- Ulusal ekonomik politika

${ }^{25}$ Düzenleme şöyledir: "MADDE 24- Türkiye Cumhuriyeti Anayasasının geçici 15 inci maddesi yürürlükten kaldırılmıştır."

${ }^{26} \mathrm{Bu}$ yasa taslağ 1 , o dönem gazetelerde , "şehirde yaşayanlara yeni vergiler” gibi başlıklar altında yer almıştı. Örn. Hurriyet Gazetesi, "Şehirde yaşayanlara yeni vergiler geliyor", 13.12.2004.

${ }^{27}$ Avrupa Konseyi bünyesinde Avrupa Yerel Yönetimler Özerklik Şartı, 8-10 Kasım 1984 tarihinde Roma'da yapılan Altıncı Yerel Yönetimlerden Sorumlu Bakanlar Kurulu Konferansında tartışılmaya açılmış ve 15 Ekim 1985 tarihi itibariyle üye ülkelerin imzalarına açılmış ve 1988 yılında uygulamaya girmiştir.

${ }^{28}$ Avrupa Yerel Yönetimler Özerklik Şartının Onaylanmasının Uygun Bulunduğuna Dair Kanun ; RG: 21.05.1991/20877 .

${ }^{29}$ Anlaşma metni için Bkz. RG: 03.10.1992/21364

${ }^{30}$ Türkiye'nin çekinceleri 4. Maddesinin 6.fikrası, 6. Maddenin, 1. Fıkrası, 7. Maddenin 3. F1kras1, 8. Maddenin, 3.F1krası, 9. Maddenin, 4. F1krası, 9.maddenin, 6. F1krası, 9. maddesinin, 7. F1krası, 10. Maddesinin, 2. F1krası, 10. Maddesinin, 3. F1krası ve 11. Maddesi ile ilgilidir. Bkz. ABGS, Avrupa Konseyi Yerel Yönetimler Özerklik Şartına İlişkin Bilgi Notu, Mayıs 2011 (ABGS,www.abgs.gov.tr, 2012) 
çerçevesinde, yerel makamlara kendi yetkileri dahilinde serbestçe kullanabilecekleri yeterli mali kaynaklar sağlanacaktır. 2- Yerel makamların mali kaynakları anayasa ve yasayla belirlenen sorumluluklarla orantılı olacaktır. 3- Yerel makamların mali kaynaklarının en azından bir bölümü oranlarını kendilerinin kanunun koyduğu sınırlar dahilinde belirleyebilecekleri yerel vergi ve harçlardan sağlanacaktır." Bu üç fikrada, Türkiye'nin Sözleşmenin 9'uncu maddesiyle ilgili çekince koyduğu fikralardan değildir ${ }^{31}$. Nitekim 3723 sayılı Yasanın 1/e fikrasında açıkça Şartın 9 uncu maddesinin 1, 2, 3 fikralarının kabul edilerek onaylandığı belirtilmiştir.

Belediye Gelirleri Kanununun belediye meclislerine alt ve üst limitler içerisinde yetki veren 96/B fikrası ile Avrupa Yerel Yönetimler Özerklik Şartının 9/3 fikrası arasında bir paralellik bulunmaktaydı. Ancak Anayasa Mahkemesinin iptal kararı, Avrupa Yerel Yönetimler Özerklik Şartının 9'uncu maddesinin üçüncü fikrası arasındaki bu paralelliği diğer bir ifadeyle "yerel makamların mali kaynaklarının en azından bir bölümü oranlarını kendilerinin kanunun koyduğu sınırlar dahilinde belirleyebilmeleri" olanağını ortadan kaldırmıştır. 1982 Anayasasının 90'ncı maddesine göre "Usulüne göre yürürlüğe konulmuş milletlerarası andlaşmalar ${ }^{32}$ kanun hükmündedir. Bunlar

319'uncu madde de Türkiye'nin çekince koyduğu 4,6 ve 7'nci fikralar aşă̆ıdaki gibidir.

"4-Yerel makamlara sağlanan kaynakların dayandığı mali sistemler, görevin yürütülmesi için gereken harcamalardaki gerçek artışların mümkün olduğunca izlenebilmesine olanak tanımaya yetecek ölçüde çeşitlilik arz etmeli ve esneklik taşımalıdır.

6- Yeniden dağıtılan kaynakların yerel makamlara tahsisinin nasıl yapılacağı konusunda, kendilerine uygun bir biçimde danışılacaktır.

7- Mümkün olduğu ölçüde, yerel makamlara yapılan hibeler belli projelerin finansmanına tahsis edilme koşulu taşımayacaktır. Hibe verilmesi yerel makamların kendi yetki alanları içinde kendi politikalarına ilişkin olarak takdir hakkı kullanmadaki temel özgürlüklerine halel getirmeyecektir.”

${ }^{32}$ Öğretide uluslararası sözleşme (convention), (treaty), anlaşma (agreement), protokol, mutabakat muhtırası (memorandum of understanding), tutanak (agreed minutes) gibi bağlayıcılığı olan çok sayıda belge uluslararası anlaşmalar olarak kabul edilmektedir. Örneğin Yargitay 10. Hukuk Dairesi 24.4.2003 tarihli ve E: 2003/1898, K: 2003/3807 sayılı Kararında uluslararası sözleşmenin uygulanmasıyla ilgili olarak “Anayasanın 90. maddesinin son fikrası hükmüne göre usulüne uygun olarak yürürlüğe konulmuş olan uluslararası sözleşmeler kanun hükmündedir. Her ne kadar tahsis talep tarihi itibariyle yürürlükte bulunan 1479 sayılı Kanunun 24/1l-b maddesi hükmüne göre Türk soylu olmayan davacının Bağ-Kur sigortalısı olması mümkün değilse de, Türkiye Büyük Millet Meclisince çıkarılan kanunla onaylanarak yürürlüğe giren ve böylece iç hukuk kuralı haline gelen "Mültecilerin Hukuki 
hakkında Anayasaya aykırılık iddiası ile Anayasa Mahkemesine başvurulamaz. Usulüne göre yürürlüğe konulmuş temel hak ve özgürlüklere ilişkin milletlerarası andlaşmalarla kanunların aynı konuda farklı hükümler içermesi nedeniyle çıabilecek uyuşmazlıklarda milletlerarası andlaşma hükümleri esas alınır. 33" "Uluslararası ilişkilerde sürekliliği sağlama amacı gözeterek getirilen "andlaşmaların yargı denetimi dışında tutulması"na ilişkin bu kuralla anayasal denetimin dışında tutulmak istenen, yöntemince yürürlüğe konulmuş olan "uluslararası andlaşmalar"dır. Bu nedenle, andlaşmadan bağımsız olarak onay yasalarına karşı Anayasa Mahkemesi'ne başvurulabilir ${ }^{34}$."Bu durumda sonuç itibariyle uluslararası sözleşme hükmü ile 1982 Anayasası düzenlemesi arasında uyumsuzluk ortaya çıkmış bulunmaktadır. Bu durum, Anayasa Mahkemesinin uluslararası anlaşmaya aykırı karar verip vermediği tartı̧̧malarını beraberinde getirmektedir ${ }^{35}$. Bu nedenle, 1982 Anayasasının 73'üncü maddesinde bakanlar kuruluna tanınan yetki benzeri bir yapıda iktisadi yapı, nüfus gibi belde özelliklerinin dikkate alınarak belediye meclislerine de en azından vergi tutarını belirleme yetkisinin tanınmasının yerinde olacağ düşünülmektedir.

Durumuna Dair Sözleşmenin (R.G. 5.9.1961 tarih ve 10898) 24. maddesinde mültecilere sosyal sigortaya (yaşlılık sigortası buna dahildir) ilişkin yasal hükümlerin aynen uygulanacağı, keza aynı doğrultudaki "Vatandaşlarla, Vatandaş Olmayan Kimselere Sosyal Güvenlik Konusunda Eşit Muamele Yapılması Hakkında 118. sayılı Uluslararası Çalışma Sözleşmesinin" (Resmi Gazete 10.8.1971 - 13922) 3 ve 10. maddelerinde mütekabiliyet şartı aranmaksızın mültecilere sosyal güvenlik hakkı tanınacağına dair hükümler karşısında aksi yönde düzenleme içeren 1479 sayılı Kanunun 24/11-b maddesi hükmünün gözardı edilerek uygulama önceliği bulunan uluslararası sözleşme hükümlerinin davaya uygulanarak, mülteci olan davacıya 1479 sayılı Kanunun 35. maddesi şartları oluştuğunda yaşlılık aylığı bağlanması gerekir." şeklinde karar vermiştir. (http://www.kazanci.com, 2012)

${ }^{33}$ Günümüzde TBMM'nin, uluslararası anlaşmalarla ilgili yetkisi, “onaylamak” değil, “onaylamayı bir kanunla uygun bulmak”tır. 924 Anayasası'nın “devletlerle mukavele ve muahede akdi” yetkisini TBMM'ye veren hükmün, 1961 Anayasası ile yürürlükten kalkmıştır. (Aybay, 2010) Ancak bu tartışmalar, çalışmamızın konusu dişında kalmaktadır.

${ }^{34}$ Anayasa Mahkemesinin 27.21997 günlü ve E: 1996/55 ve K: 1997/33 say1lı Kararı.

${ }^{35}$ Birçok ülkede uluslararası anlaşmaların yürürlüğe girmeden önce Anayasaya uygun olup olmadığının denetimi yaygın olarak uygulanan bir yöntemdir. Ancak Türkiye'de böyle bir uygulama bulunmamaktadır. Diğer ülke örnekleri için Bkz. Başlar, 2004. Ayrica Aybay, 2010. 


\section{Değerlendirme}

Birçok ülkede merkezi yönetim ile yerel yönetimler arasında gelir paylaşımında etkin olan ve gelirin çoğunluğunu alan taraf merkezi yönetimdir. $\mathrm{Bu}$ Türkiye için de geçerlidir. Ancak devletlerin örgütlenme biçimi ve bu bağlamda federal mi yoksa merkezi bir devlet yapısına mı sahip oldukları sorununun yanıtı gelir paylaşımı ve vergilendirme yetkisinin devri konusunda belirleyici olabilmektedir. 2464 sayılı Yasada yer alan vergi türleri, sağladıkları gelirler açısından belediyeler için toplumsal ve ekonomik yapılarına göre farklı önemlerde olabilmektedir. Türkiye Belediyeler Birliği verilerine göre 2012 yılında Türkiye'de 2.950 belediye bulunmaktadır. Dolayısıyla örneğin büyükşehir belediyeleri ile belde (kasaba) belediyelerinin topladıkları gelirler, aynı Yasa uygulamasından doğsa da bazı kaynaklar bazı bölgelerde daha önemli gelir kaynağı olabilmektedir. Örneğin eğlence vergisi büyük şehirlerde önemli bir gelir kaynağı olabilirken hiç sinemanın bulunmadığı küçük yerleşim yerlerinde önemsiz olabilmektedir. Ayrıca uygulamadan doğan sorunlar, vergilerin toplanmasına etkide bulunabilmektedir. Genellikle bir sonraki seçimleri düşünmek zorunda olmak ya da vergi toplam konusunda etkin bir idari birim kurma konusunda yaşanan sorunlar, belediyelerin vergi gelirlerine doğrudan olumsuz olarak etkide bulunabilmektedir.

Anayasa Mahkemesinin 2464 sayılı Yasanın 96/B maddesinde yer alan "Bazı vergi ve harçların maktu tarifeleri; Yasada belirtilen en alt ve en üst sınırları aşmamak şartıyla mahallin çeşitli semtleri arasındaki sosyal ve ekonomik farkl11ıklar göz önünde tutularak belediye meclislerince tespit olunması" düzenlemesine ilişkin iptal kararı, yerel yönetimlerin vergilendirme yetkisine sahip olup olmadıkları konusundaki temel bir tartışmayı 1982 Anayasasında yer alan vergilendirme ile ilgili kurallarını dikkate alınarak sonlandırmıştır. Ancak Anayasa Mahkemesi bu kararını, 12 Eylül döneminde çıkarılan yasalara karşı Anayasa Mahkemesine başvurulabilmesini yasaklayan 1982 Anayasasının Geçici 15'nci maddesinin yürürlükten kaldırılmasından sonra verdiğini özellikle vurgulamak gerekmektedir.

$\mathrm{Bu}$ Karar ayrıca 1948 yılında uygulama giren 5237 sayılı Yasa kapsamında belediye meclislerine tanınan yetkinin iptaliyle ilgili kararlardan gerekçesi yönüyle farklılık göstermektedir. 5237 sayılı Yasa döneminde verilen iptal kararlarının gerekçesi "tavan kanunda yer almamış ve yürürlükte bulunan, sınırsız ve keyfi uygulamalara elverişli metin" olmasına karşılık 2464 sayılı Yasada yetkiyle ilgili iptal gerekçesi ise belediye meclislerinin alt ve üst sınırlar belirtilmiş olsa bile böyle bir yetkiye sahip olmamaları gerekçesine dayanmıştır. Ancak belediye meclislerinin bölgenin özelliklerini dikkate alarak vergi tutarını belirleme yetkisinin iptal edilmesi aynı zamanda vergi adaletiyle ilgili olumsuz sonucun ortaya çıkmasına neden olabilecektir. Çünkü bu 
durumda, farklı bölgelerde yaşayan bireylerin ödeme güçlerinin aynı olduğu kabul edilmek zorunda kalınacaktır.

Diğer taraftan her iki Yasada da kullanılan vergi ile ilgili tanımlamalar, bazı durumlarda vergi terminolojisi ile uyumlu değildir. Örneğin 2464 sayılı Yasanın 44'üncü maddesinde tanımlanan çevre ve temizlik vergisinin, isminde geçmekle birlikte gerçekte vergi mi olduğu yoksa belediyelerce görülen bir hizmetin bedeli mi olduğu konusunda farklı görüşler bulunmaktadır. Bazı kaynaklar, çevre ve temizlik vergisinin gerçekte vergi olmadığını belirtmektedir. Bu durumda örneğin, belediye meclislerinin bu vergiyle ilgili karar alması düzenlemesi, Anayasanın 73'üncü maddesiyle bağdaşmaz mı sorusunun gündeme gelmesine neden olmaktadır.

Konunun farklı bir boyutu ise Avrupa Yerel Yönetimler Özerklik Şartı ile ilgilidir. Belediye Gelirleri Kanununun belediye meclislerine yasa ile belirlenen alt ve üst limitler içerisinde vergi tutarını belirleme yetkisi veren düzenlemeleri ile Avrupa Yerel Yönetimler Özerklik Şartının "yerel makamların mali kaynaklarının en azından bir bölümü oranlarını kendilerinin kanunun koyduğu sınırlar dahilinde belirleyebilecekleri yerel vergi ve harçlardan sağlanması" ile ilgili kuralı arasındaki uyumluluk Anayasa Mahkemesinin söz konusu kararı ile ortadan kalkmaktadır. Bu durumda, 1982 Anayasasının belirli bir dönemde çıkan yasalara karşı Anayasa Mahkemesine başvurulmasını yasaklayan düzenlemesinin yürürlükten kaldırılmasından sonra, Anayasa Mahkemesinin bu dönemde çıkan Yasalara karşı artık iptal kararı verebilmesi gibi olumlu bir sonuç ortaya çıkarken diğer taraftan Avrupa Yerel Yönetimler Özerklik Şartının belediye meclislerinin yasanın koyduğu sınırlar içerisinde yerel vergi ve harçlar konusunda karar verebilmesinin sağlanması kuralının ihlal edilmesi gibi olumsuz bir sonuç da ortaya çıkmaktadır. $\mathrm{Bu}$ ikilemin giderilmesi ise konunun siyasi, hukuki ve iktisadi boyutlarıyla birlikte değerlendirilmesiyle mümkündür. $\mathrm{Bu}$ nedenle, Anayasanın vergilendirme ile ilgili kuralları düzenleyen 73'üncü maddesinde değiş̧ikliğe gidilerek, belediye meclislerine de en azından bakanlar kuruluna tanındığ gibi yasada belirlenen sınırlar içerisinde vergilendirme yetkisi tanınmasının yerinde olacağı sonucuna varılmaktadir. 


\section{Kaynakça}

ABGS (2011), Avrupa Konseyi Yerel Yönetimler Özerklik Şartına İlişkin Bilgi Notu, http://www.abgs.gov.tr/files/haberler/2011/yerel_yonetimler_ozerklik___ sarti.pdf. $(11 / 07 / 2012)$.

Akalın, Güner (1994), "Türkiye'de Mahalli İdareler Hizmetleri ve Finansmanı Reformu”, TODAI Çağdaş Yerel Yönetimler Dergisi, Cilt 3, Sayı:2: 11- 24. Aktan, Tahir (1974), "Mahalli İdarelerin Bazı Sorunları Üzerine", TODAI Amme Idaresi Dergisi Cilt: 7 Sayı:2:101-114.

Aybay, Rona, (2010), "Anayasa Mahkemesi ve Uluslararası Anlaşmalar”, Cumhuriyet Gazetesi, 26/07/2010.

Başlar, Kemal (2004), “Uluslararası Anlaşmaların Onaylanması, Üstünlüğü ve Anayasal Denetimi Üzerine", Milletlerarası Hukuk ve Milletlerarası Özel Hukuk Bülteni: Prof. Dr. Sevim TOLUNER'e Armağan, http://www.anayasa.gen.tr/baslar-90nciMadde.pdf $(15 / 07 / 2012)$

Blöchliger Hansjörg (2006), Fiscal Autonomy of Sub-Central Governments, OECD COM/CTPA/ECO/GOV/WP(2006)/2.

Blöchliger, Hansjörg - RABESONA, Josette (2009), The Fiscal Autonomy of Sub-Central Governments: An Update, OECD COM/CTPA/ECO/GOV/WP(2009)9.

Buchanan (1950), "James M, Federalism and Fiscal Equity", The American Economic Review , Vol. 40, No. 4, Sep: 583-599.

Çağan, Nami (1980), Demokratik Sosyal Hukuk Devletlerinde Vergilendirme" Ankara Üniversitesi Hukuk Fakültesi Dergisi, AUHF-1980-37-01-04: 129-151.

Çağan, Nami (1982), Vergilendirme Yetkisi, (İstanbul: Kazancı Hukuk Yayınları).

Çağan, Nami (1984), "Türk Anayasası Açısından Vergileme Yetkisi”, Anayasa Yargısı Dergisi, Yıl: 1984, No: 1: 171-183.

Çubukçu, Dilek Özkök (2010), "Avrupa Birliği Çerçevesinde Yerel Yönetimler ve Gelir Yapıları”, AU Siyasal Bilgiler Fakültesi Dergisi, Sayı: 63 , Cilt :1:41-80.

Duran, Lütfü (1982), İdare Hukuku Ders Notları (İstanbul: IÜ Hukuk Fakültesi No: 648).

Ergin, Osman Nuri (1995), Mecelle-i Umur-ı Belediyye Cilt 3, İstanbul Büyükşehir Belediyesi Yayını No.21'den aktaran ÖNER, Erdoğan (2008), İstanbul Şehremaneti (Belediyesi)'nin Kuruluşu ve 1917 yılı Bütçesi (Ankara: T.C. Maliye Bakanlığı Strateji Geliştirme Başkanlığı Yayın No: 2008/386).

Falay, Nihat (1997), “Türkiye'de Yerel Yönetimlerin Mali Yapısına İlişkin Eğilimler”, TODAi Çağdaş Yerel Yönetimler Dergisi Cilt :6, Sayı :2: 4-13.

Gerek, Şahnaz, Ali Rıza Aydın (2005), Anayasa Yargısı ve Vergi Hukuku (Ankara: Seçkin Yayınları). 
Geray, Cevat (1977), "Belediyelerimizin Yapısal Sorunları", AÜ Siyasal Bilgiler Fakültesi Dergisi, Cilt 32, Sayı 1: 33-48.

Güler, Birgül (2000), "Yerel Yönetimleri Güçlendirmek mi? Ademi Merkeziyetçilik mi?”, Çağdaş Yerel Yönetimler Dergisi, 9/2, Nisan 2000: 14-29.

Kazancl, http://www.kazanci.com/cgi-bin/highlt/ibb/ highlight.cgi?file=ibb/files/10hd-20031898.htm\&query=\% 222003/ 1898\% 22\#fm (8/9/2012).

Hürriyet Gazetesi (2004), "Şehirde yaşayanlara yeni vergiler geliyor”, 13.12.2004.

Journard, Isabelle, Kongsrud Per Mathis (2003), Fiscal Relations Across Government Levels, OECD Economic Studies No. 36, 2003/1.

Keleş, Ruşen (1965), "Bölgesel ve Mahalli İdarelerin Planlı Kalkınmadaki Rolü”, AÜ Siyasal Bilgiler Fakültesi Dergisi, Sayı: 20, Cilt:1: 419- 426.

Keleş, Ruşen (1972), "Belediye Gelirleri Kanunu ve Mali Denkleşme", TODAl Amme Idaresi Dergisi, Sayı: 5/2: 58-75.

Kumrulu, Ahmet (1988), "Türkiye'de Vergi Politikası Gelişmeleri: Karar Alma Süreci ve Sapmalar (1950-1985)", AUHF-1988-40-01-04: 193-235.

Küsmenoğlu, İlhan (2010), Vergi Tarihi 1. Kitap Osmanlı Devletinden 1980'e, (Ankara: Oluş Yayıncılık).

Leba, Reyhan (2001), "Mali Anayasa Üzerine Düşünceler ve Türkiye'nin Gerçekleri”, Amme İdaresi Dergisi, Cilt 34 Sayı: 2: 53-67.

Maliye Bakanlığı (1989), Türk Vergi Kanunları Gerekçeleri, 2464 sayılı Belediye Gelirleri Kanunu Genel Gerekçe Kanun Tasarısı ve Komisyon Raporları (Ankara).

Muratlıoğlu, Tahir (2011), "Avrupa Yerel Yönetimler Özerklik Şartı ve Türk Hukuku”, ï̈HFM C. LXIX, S.1-2: 737-776.

Oates, Wallace E. (1968), "The Theory of Public Finance in a Federal System", The Canadian Journal of Economics / Revue canadienne d'Economique, Vol. 1, No. 1. (Feb.1968): $37-54$.

OECD (2011), Revenue Statistics 1965-2010 (Paris).

Okandan, G. Recai (1976), Umumi Amme Hukuku, (İstanbul: İstanbul Üniversitesi Yayınları No: 2138, Hukuk Fakültesi No: 479).

Ortaylı, İlber (1982), "Osmanlı İmparatorluğunda İdari Modernleşme ve Mahalli İdare Alanındaki Gelişmeler", Idare Hukuku ve Ilimleri Dergisi, Cilt 3, Sayı 1-3: 137-148.

Öncel, Mualla, Kumrulu Ahmet, Çağan Nami (2011), Vergi Hukuku, 20.Bası, (Ankara: Turhan Kitabevi).

Öner, Erdoğan (2005), Osmanlı Imparatorluğu ve Cumhuriyet Döneminde Mali İare, 2. Baskı, (Ankara: Maliye Bakanlığı APKK Başkanlığı). 
88 • Ankara Üniversitesi SBF Dergisi • 67-4

Öner, Erdoğan (2012), Vergi Hukuku ve Türk Vergi Sistemi (Ankara: Seçkin Yayıncılık).

Öz, N. Semih (2005), "Devletlerin Vergilendirme Yetkisinin Dikey Paylaşımı", Vergi Sorunları Dergisi, Yıl: 28, Sayı: 20: 21-35.

Reuter, Ernst (1943) , "Belediye Maliyesinin Umumi Meseleleri”, Siyasal Bilgiler Okulu Dergisi, Sayı, I, Cilt 1: 108-142.

Reuter, Ernst (1945) , "istanbul Belediyesinin Mali Durumu (1937-1942)", Siyasal Bilgiler Okulu Dergisi, C. 1, No: 3: 489-503.

Rodden, Jonathan (2003), Reviving Leviathan: Fiscal Federalism and the Growth of Government, International Organization, Vol. 57, No. 4 (Autumn, 2003): 695-729.

Stiglitz, Joseph E.(2000), Economics of Public Sector (W.W. Norton \& Company).

Tan, Turgut (1994), "1982 Anayasası'nın Geçici 15. Maddesi Üzerine”, AU Siyasal Bilgiler Fakültesi Dergisi, Cilt : 49, Sayı: 1: 373-385.

Tezsezen, Cumhur, Ağaçlı Ömer (1995), Türkiye'de Yerel Yönetim Sistemi Içerisinde Belediyeler, (Ankara: Maliye ve Hukuk Yayınları).

Yayla, Yıldızhan (1982), Anayasalarımızda Yönetim Illkeleri Tevsi-i Mezuniyet ve Tefrik-i Vezaif (stanbul: IU Siyasal Bilimler Fakültesi Yayın No: 56).

Yüksel, Fatih (2007), "Sosyal Devletin Dönüşüm Sürecinde Yerel Yönetimlerin Yeni İşlevleri”, $A U$ Siyasal Bilgiler Fakültesi Dergisi, Sayı 62, Cilt: 1: 279-298. 